\title{
APPLICATION OF ARTIFICIAL NEURAL NETWORK METHOD AS A DETECTION OF BLOOD FAT DISORDERS IN IMAGES OF COMPLETE BLOOD EXAMINATION
}

\author{
Catharina Natasa Bella Fortuna ${ }^{1}$, Franky Chandra S.A. ${ }^{2}$, Puspa Erawati ${ }^{3}$ \\ 1,2,3 Biomedical Engineering Study Program, Department of Phisics, Faculty of Science and Technology, \\ Universitas Airlangga, Surabaya, Indonesia \\ Article History \\ Received : July 2021, Revised : August 2021, Accepted : September 2021, Online : December 2021
}

\begin{abstract}
Based on various epidemiological studies, it is stated that blood lipids are the main risk factor for atherosclerosis that leads to coronary heart disease. In patients with blood lipid disorders, red blood cells undergo deformability so that their shape is flatter than normal red blood cells, which are round. The research entitled Application of Artificial Neural Network Method as Detection of Blood Fat Abnormalities in Image of Complete Blood Examination Results was conducted to help facilitate laboratory examinations. This research hopes that it will provide appropriate early detection to support the expert diagnosis. This research consists of two stages. The first stage is digital image processing to obtain area, perimeter, and eccentricity features. These three features will be used as input to the Backpropagation Neural Network program as the second stage. At this stage, blood lipid abnormalities are detected from features that have been obtained from image processing. The accuracy of detecting blood lipid abnormalities with ANN Backpropagation is $85 \%$. Keywords: Artificial Neural Networks, Backpropagation, Image Processing of Blood Fat Abnormalities, Coronary Heart, Detection
\end{abstract}

\section{INTRODUCTION}

Coronary Heart Disease (CHD) is the leading cause of death in the world. Many studies have been carried out on various risk factors from the onset of atherosclerosis, changes in coronary blood vessels to be detected earlier to reduce mortality and the number of patients with CHD. Based on various epidemiological studies, it is stated that blood lipids are the main risk factor for atherosclerosis that leads to CHD. Therefore, it is necessary to apply a laboratory diagnosis of abnormalities in blood lipids.

The most common laboratory test is a complete blood count. Through HDL, it is possible to identify the fat content in the blood by examining its lipid content. Examinations carried out in the laboratory utilize biochemical methods and are quite time consuming to obtain overall results in examining blood lipids. So, the use of computational technology is needed in developing a faster and more accurate inspection method. A previous study by Narayanan et al. (2009) can identify normal blood and blood with blood lipid cholesterol abnormalities in hypercholesterolemic patients by observing the shape of the blood.

This research is expected to provide an initial picture, especially to support the diagnosis to determine whether a person has the potential to be affected by CHD or not. The Back Propagation artificial neural network algorithm is suspected to be precise and is widely used in several types of research and identification of medical images. In identifying the image, digital image data is used as input data on the Artificial Neural Network (ANN) for learning. After the learning is complete, the Artificial Neural Network can be used in other image recognition. ANN is then applied by taking samples of objects that have been processed with an image processing system.

\section{Blood Fat Cholesterol Check}

Hypercholesterolemia is one of the main risk factors for Coronary Heart Disease (CHD). The risk factor for this blood lipid disorder is an important problem because cholesterol, fat and other substances can cause thickening 
of the walls of the arteries so that the lumen of the blood vessels narrows. The process of narrowing of blood vessels due to the accumulation of fat is called Atherosclerosis. This narrowing of blood vessels will cause blood flow to be slow and even blocked so that blood flow in the coronary arteries is reduced and oxygen transport is hampered.

A previous study by Narayanan et al. (2009) can identify normal blood and blood with blood lipid cholesterol abnormalities in hypercholesterolemic patients by observing the shape of the blood. Blood components that are easily observed are red blood cells or erythrocytes. In this study, the shape of red blood cells in patients with hypercholesterolemia was not round as in normal blood. This behaviour is due to the deformability of erythrocytes found in blood with blood lipid disorders.[9] Deformability is caused by the pressure of blood lipids around erythrocytes which have a greater viscosity than blood cells and cause changes in shape. These changes were measured from the surface area and circumference of erythrocytes. In addition, eccentricity or elliptical shape also determines the presence or absence of blood lipid abnormalities in patients. Another study by Zulkifli Tahir and Elly Warni, Indrabayu and Ansar Suyuti also researched red blood cell disease recognition by using blood images based on artificial neural networks. [21];[23]

\section{Preparation of Blood Smears}

The purpose of making a blood smear is to examine peripheral blood, such as red blood cells, white blood cells, and blood platelets. The preparation of a good blood smear is an absolutely important requirement to get the best test results. Making blood smears requires patience and care so that the resulting smear is good to observe later. How to make preparations is with two pieces of object-glass. One as a slide, the other as a spreader. The spreader or tool used to spread red blood cells must be larger than the slide so that the smear obtained can be more easily observed under a microscope. The spreader is placed at an angle between $25^{\circ}$ to $30^{\circ}$ in front of the droplet on the slide and then pulled back. [1]

\section{Digital Microscope}

In current studies, the use of a microscope is still relevant and following research developments. The type of microscope that is practical and has been widely used in research, and is easy to operate is a digital microscope. The digital microscope is connected directly to a computer so that the observed image data can be directly observed and processed digitally.

The incident ray passing through the lens has a slower speed than the propagation of light in air or a vacuum. This condition is because the light must pass through the thickest part to the thinnest part of the lens. The shape of the convex surface of the lens causes the distance of light that hits the lens to vary, so that light rays are bent towards the lens's optical axis. This phenomenon is called the refraction of light. [24] In a microscope, the Numeric Aperture (NA) is also known, which is a number that indicates the ability of the lens to collect light.

\section{Digital Image Processing}

A digital image is a function of light intensity $f(x, y)$, where the values of $x$ and $y$ are the spatial coordinates and the value of the function. Digital images are usually rectangular; visually, the dimensions are expressed as width $\mathrm{x}$ height. Its size is expressed in points or pixels (pixel = picture element) and can also be expressed in length units $(\mathrm{mm}$ or inch $=\mathrm{inch})$. Digital images are represented by a size $\mathrm{N}$ x M ( $\mathrm{N}$ represents rows or heights, $\mathrm{M}$ represents columns or widths. The obtained digital images must be processed first through various methods to improve image quality and produce new images as desired. This process is intended to facilitate the identification process in artificial neural networks. The image processing methods used include the following:

\section{Pre-Processing}

One of the pre-processing stages is grayscale. By changing the RGB (Red, Green, Blue) value representation, a colour image is converted into an image consisting of white and black gradations, usually called a grayscale image. A pixel in a colour image is composed of three colours, namely red, green, and blue or ordinary (Red, Green, and Blue / RGB), which have a pixel value of at least 0 and a maximum of 255. Grayscale images are stored in the format of 8 bits for each sample pixel, which allows as many as 256 intensities. 


\section{Segmentation}

Segmentation is used to cut or partition an image into several areas or image objects processed into several parts [14]. One method in the segmentation process is Thresholding. The threshold is also known as image floating. From the grayscale image, the threshold process can be shown by the following equation:

$$
g(x, y)=\left\{\begin{array}{l}
1 \text { if } f(x, y)>=T \\
0 \text { if } f(x, y)<T
\end{array}\right\}
$$

In the equation, $g(x, y)$ is a binary image of a colour image or a grayscale image of $f(x, y)$, and $T$ represents a threshold value. The $\mathrm{T}$ value plays a very important role in the thresholding process. The quality of the binary image is highly dependent on the T value used (Putra, 2010). The thresholding process will change pixels above the threshold value to become white pixels (value $=1$ ) and change pixels below the threshold value into black pixels (value $=0$ ).

In this study, the thresholding process is used to segment or separate areas in the image that are the object of research from areas that are not needed. The segmented area in a single red blood cell image is the red blood cell area separated from the background, where the red blood cells will be a white area, while the background is a black area. The method used in thresholding is the otsu method.

\section{Otsu Method}

The Otsu method calculates the threshold value $\mathrm{T}$ (threshold) automatically based on the input image. The approach used by the Otsu method is discriminant analysis, which is to determine a variable that can distinguish between two or more groups that arise naturally. The discriminant analysis will maximize these variables in order to separate objects from the background [15].

The threshold value to be searched is expressed by $\mathrm{k}$. The value of $\mathrm{k}$ ranges from 1 to $\mathrm{L}$, with $\mathrm{L}=255$. The probability for pixel $\mathrm{i}$ is expressed by:

$$
p_{i}=\frac{n_{i}}{N}
$$

Where $n \_i$ represents the number of pixels with a gray level $\mathrm{L}$, and $\mathrm{N}$ represents the number of pixels in the image. The value of the cumulative moment to zero, the cumulative moment to one and the average, respectively, can be expressed as follows:

$$
\begin{gathered}
\omega(k)=\sum_{i=1}^{k} p_{i} \\
\mu(k)=\sum_{i=1}^{k} i \cdot p_{i} \\
\mu_{T}=\sum_{i=1}^{L} i \cdot p_{i}
\end{gathered}
$$

The threshold value $\mathrm{k}$ can be determined by maximizing the between-class variance, which is defined as:

$$
\sigma_{B}^{2}(k)=\frac{\left[\mu_{T} \omega(k)-\mu_{T}(k)\right]^{2}}{\omega(k)[1-\omega(k)]}
$$

The Matlab toolbox provides a graythresh function that calculates the threshold using the Otsu method. The syntax for calling the graythresh function is "T= graythresh (f)", where $\mathrm{f}$ is the input image, and $\mathrm{T}$ is the resulting threshold [14].

\section{Binary Image Morphology}

Morphological image processing is a way to extract or modify information about the shape and structure of objects in an image. There are several types of morphological operators, but the two most basic operations are dilation and erosion. All other morphological operations are built on the combination of the two operations. [2]. Additional operations performed in this study are filling holes. These filling holes are used to fill the center of the hole. A hole is defined as a background area surrounded by a boundary of connected foreground pixels [22]. To fill the holes, the point in each hole (holes), FM, is assigned a value of 1 (for binary images) at all points until it reaches the edge of the border, 1-f [3]. 


\section{Feature Extraction}

The binary image obtained from the segmentation is then extracted its features or features. These characteristics will then become the basis for the identification process using an artificial neural network. The characteristics of a good feature meet the following requirements [15].

1. Can distinguish an object from another (discrimination).

2. Pay attention to the computational complexity in obtaining features. High computational complexity will be a burden in finding a feature.

3. Independent, in the sense of being invariant to various transformations.

4. The number is small because the few features will save computing time and storage space for the next process (feature utilization process).

In this study, the features used are area, area, and eccentricity. The red blood cell area is a scalar value that states the total number of red blood cell pixels after filling holes. Perimeter is the sum of each pixel that has an intensity value of one using the bwperim command. Eccentricity is the ratio of the distance between the center of an elliptical object to the length of its principal axis. An ellipse with an eccentricity of 0 is a circle, while an ellipse with an eccentricity of 1 is a line segment. The general syntax provided by the Matlab toolbox for process eccentricity is:

properties = regionprops (labeledImage, 'eccentricity'); eccentricities $=$ [props.Eccentricity];

\section{Artificial Neural Network}

An artificial neural network is an information processing system similar to biological neural networks [18]. The Artificial Neural Network (ANN) method is useful in several uses, including detection, identification, and control. Artificial Neural Networks are designed to solve a problem with learning techniques.

\section{Artificial Neural Network Architecture}

Some of the network architectures that are often used in artificial neural networks include:

a. Single Layer Network

In this network, a set of input neurons are connected directly to their outputs. An example of a single screen model ANN is the Perceptron.

b. Multiple Screen Network (multi-layer network)

Multi-layer ANN is an extension of a single layer. In this network, besides the input and output units, there are other units called hidden screens. Just as in the input and output units, the units in one display are not interconnected.

\section{Activation Function}

In ANN, the output of the neuron is determined by an activation function. The tangent used is (sigmoid tangent.)

\section{Bias}

In ANN, one unit is often added, which has a value of $=1$. This unit is called Bias. Bias serves to change the threshold value to $=0$.

\section{Artificial Neural Network Training}

Based on the method for modifying weights, there are two types of ANN training: supervised and unsupervised.

\section{Backpropagation Neural Network}

The Backpropagation neural network algorithm is easy to understand and used in several medical image identification studies. In identifying the image, digital image data is used as input data on the Artificial Neural 
Network for learning. After the learning is complete, the Artificial Neural Network can be used in other image recognition.

Backpropagation is one of the developments of the Single Layer Neural Network architecture. This architecture consists of an input layer, a hidden layer and an output layer, and each layer consists of one or more artificial neurons. The common name for this architecture is Multilayer neural network.

\section{Artificial Neural Network Training}

The purpose of the Artificial Neural Network training is to obtain the right weight value for each layer.

\section{Supervised learning process}

There is an expected target according to the input-output pair being trained. After going through the training process, a network can be used to remember a pattern. When a new input is entered, the resulting output is expected to match the existing pattern.

In detail, training using the Backpropagation method goes through the following steps:

Step 0: Initializing weights and biases.

Weights and bias values can be set at random, usually around 0 and 1 or -1 (positive or negative bias).

Step 1: If the value obtained is still not as expected in the stopping condition, then steps 2 to 9 .

Step 2: For each training data, steps 3 to 8.

\section{Feedforward}

Step 3: Each input unit receives an input signal. The input signal is sent to all hidden units. The input used is the training data input that has gone through scaling. The highest and lowest values of the input used in the system are then searched. The scale used is adjusted to the activation function. When using a binary sigmoid with the lowest price $=0$ and the highest price $=1$, the lowest input value is also considered $=0$ and the highest value is considered $=1$. The values between them vary between 0 and 1 . Meanwhile, when using a bipolar sigmoid, the range of values also varies from 0 to $1 .-1$ to 1 .

Step 4: Each hidden unit is the sum of the weighted input signals and their biases with Equation 7.

$$
Z_{-} i n_{j}=V_{0 j}+\sum_{i=1}^{n} X_{i} V_{i j}
$$

To calculate the value of the output signal from the hidden unit, the activation function that has been selected is used, with Equation 8.

$$
Z_{j}=f\left(Z_{-} i n_{j}\right)
$$

Then the output signal from the hidden unit is sent to each output unit. 9.

Step 5: Each output unit is the sum of the input signals that have been weighted and their biases, with equation

$$
Y_{-} i n_{k}=W_{0 k}+\sum_{j=1}^{p} Z_{j} W_{j k}
$$

To calculate the value of the output signal from the output unit, the activation function that has been selected is used, with the equation 10.

$$
Y_{k}=f\left(Y_{-} i n_{k}\right)
$$

Step 6: Each output unit receives a target pattern (desired output) according to the input training pattern to calculate the error between the target and the output, with the equation:

$$
\delta_{k}=\left(t_{k}-Y_{k}\right) f^{\prime}\left(Y_{-} i n_{k}\right)
$$

Like the training data input, the training data output also goes through scaling according to the activation function used. The factor serves to calculate the error correction that will be used in updating the value of $\mathrm{W}_{\mathrm{jk}}$.

$$
\Delta W_{j k}=\alpha \delta_{k} Z_{j}
$$

Bias Correction $\left(\Delta W_{0 k}\right)$ was used to get $W_{0 k}$.

$$
\Delta W_{0 k}=\alpha \delta_{k}
$$

$\delta_{k}$ was sent to step 7 . 
Step 7: The weighted input delta (from the layer in step 6) is summed for each hidden unit $\left(Z_{j}, j=1,2, \ldots, p\right)$.

$$
\delta_{-} i n_{j}=\sum_{k=1}^{m} \delta_{k} W_{j k}
$$

In order to produce an error correction factor, the result of equation (2-8) is multiplied by the derivative of the activation function used.

$$
\delta_{j}=\left(\delta_{-} i n_{j}\right) f^{\prime}\left(Z_{-} i n_{j}\right)
$$

A factor $\delta_{j}$ was used to calculate error correction $\left(\Delta V_{i j}\right)$, which will be used for updating the value $V_{i j}$, with Equation 16 :

$$
\Delta V_{i j}=\alpha \delta_{j} X_{i}
$$

Bias correction $\left(\Delta V_{0 j}\right)$ which will be used in the update $V_{0 j}$

$$
\Delta V_{0 j}=\alpha \delta_{j}
$$

\section{Wieght and Bias Adjustment}

Step 8: Each output unit $\left(Y_{k}, k=1,2, \ldots, m\right)$ will be used to update the bias value and weight of each hidden unit $(j=0,1, \ldots, p)$.

$$
W_{j k}(\text { baru })=W_{j k}(\operatorname{lama})+\Delta W_{j k}
$$

Each hidden unit $\left(Z_{j}, j=1,2, \ldots, p\right)$ will also be used to update the bias value and weight of each input unit $(i=0,1, \ldots, n)$.

$$
V_{i j}(\text { baru })=V_{i j}(\text { lama })+\Delta V_{i j}
$$

Step 9: Check the stop condition.

If the stop conditions are met, the Artificial Neural Network training can be stopped.

\section{RESEARCH METHODS}

\section{Sample Data Collection}

The collection of research sample data includes the acquisition of blood that has been tested in the laboratory. The data collection process was performed by capturing blood smear preparations using a digital microscope directly connected to a computer/laptop. The image obtained from these results is then cropped to obtain a single blood image. The sample images used include single blood images grouped into normal blood cells and blood cells with blood lipid abnormalities. The sample and the diagnosis were obtained from the Prodia Clinical Laboratory.

\section{Feature Extraction}

The blood feature determination stage begins with converting a grayscale image into a binary image using thresholding. The thresholding process causes holes in the blood; therefore, filling holes are carried out to fill the hollow cells [11]. After the hole is filled, the total number of blood pixels (white pixels) is calculated to get the blood area. This blood area shows the size of the blood, which will later be compared with the size of normal blood. In addition to the area, the perimeter of the blood is also calculated. After calculating the area and perimeter, eccentricity is calculated to make the detection more accurate. In the blood with abnormal lipids, the area and perimeter have smaller amounts than normal blood. Eccentricity in blood with blood lipid abnormalities shows a shape that tends to be more flat (ellipse) than normal blood.

\section{Artificial Neural Network Learning}

The result of feature extraction then becomes the input for the Artificial Neural Network. The results of the blood fat image are grouped into two groups, namely normal blood and blood with symptoms of blood fat disorders. At this stage, 40 training samples and 20 test samples were used. In training on the backpropagation 
neural network model, pattern learning was carried out from 40 blood image data on backpropagation artificial neural network software; the flowchart of the training data process is presented in Figure 1.

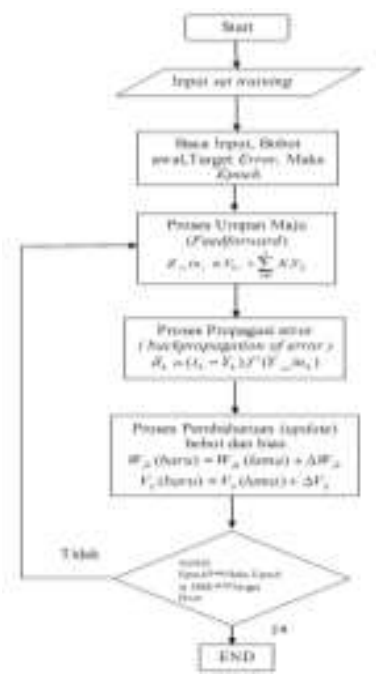

Figure 1. Learning Algorithm

\section{Artificial Neural Network Testing}

The data testing process uses the weight and bias values from the data training process results to produce the backpropagation artificial neural network software classification later. This testing process was carried out on 23 blood lipid abnormality signal data compared to the target value; the flowchart of the data testing process is presented in Figure 2.

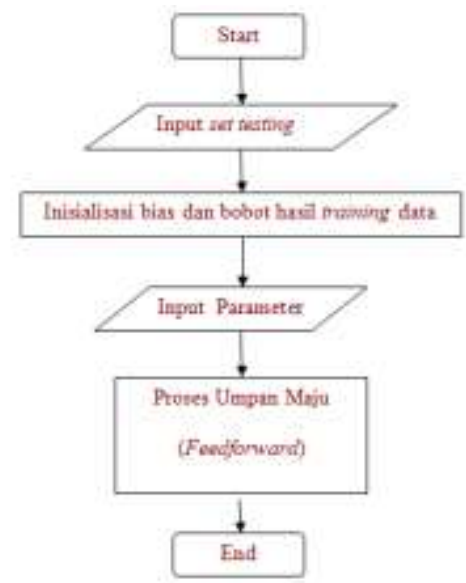

Figure 2. Data Testing Algorithm

\section{Data Analysis and Implementation}

Artificial neural network analysis to identify blood lipid abnormalities was carried out based on a comparison between the introduction of blood fat disorders from a cardiologist with the learning process of blood fat abnormality patterns from the software. To obtain a system with a high level of accuracy is also determined by selecting the right network architecture and network training parameters. Backpropagation ANN fulfils these requirements.

In the training data, the learning rate and maximum epoch variations will be carried out so that later the MSE (mean square error) value is constant (convergent), and the maximum accuracy is obtained. For data testing, a comparison is made between the medical diagnosis results from laboratory examinations and the software's classification results (Febrianty et al., 2007).

The accuracy of the backpropagation artificial neural network is based on two main things, namely the accuracy of the system that is required to be able to recognize the patterns that 
have been taught and similar patterns and the accuracy of the data during the initial learning of the introduced pattern.

\section{RESULT AND DISCUSSION}

\section{Data processing}

The digital image of the blood is obtained through the capture results then cropped to image a single red blood cell. From the results of cropping, the image obtained is then grouped into two groups. Blood group with blood fat abnormalities and normal blood. Cropping results are shown in Figure 3.

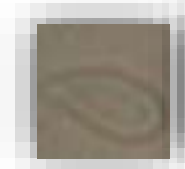

(a)

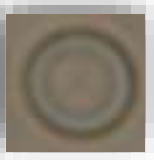

(b)

Figure 3. Cropping Citra Blood. (a) blood with blood fat abnormalities, (b) normal blood

\section{Pre-Processing}

The pre-processing stage in this study includes a greyscale process that aims to convert an RGB image into an image with a gray level of $0-255$. The data that is processed at this grayscale stage is the cropped data. The result of changing the digital image through the grayscale process can be seen in Figure 4.

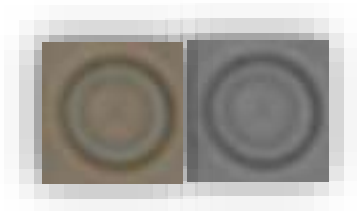

(a)

(b)

Figure 4. (a) RGB Image, (b) grayscale Image

\section{Segmentation}

After the cropping process is continued with the segmentation process, this process aims to separate the red blood cell image from the background image. Segmentation is done by providing a certain threshold value using the Otsu method through the Matlab toolbox. The syntax for calling the graythresh function is "T=graythresh (f)", so the resulting $\mathrm{T}$ (threshold) value will vary according to the processed image. The image intensity value above the threshold value will be 0 or black, while the image intensity value below the threshold value will be one or white. The image generated through this process is a binary image.

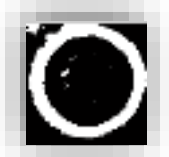

Figure 5. Segmented Image 


\section{Morphology Operation}

The morphological operation used in this research is the filling holes operation. Filling holes surgery is required to calculate the red blood cell area. Because the middle part of the red blood cells, called the achromia section, has the same color as the background, it causes holes in the image after thresholding. Therefore, the operation of filling holes plays a role in filling these holes. The filling holes operation process is shown in the picture.

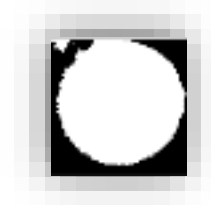

Figure 6. Filling Holes Processed Image

\section{Calculation of Area, Perimeter and Eccentricity}

The filling holes process is followed by calculating red blood cells the area, perimeter, and eccentricity. The calculation of the area and perimeter in the image distinguishes between blood with abnormal blood lipids and normal blood. The area calculation can be done by counting the number of pixels with an intensity value of one, namely white pixels. Perimeter calculation is calculating the perimeter of an image. The segmented image then calculates the perimeter using the bwperim command and adds up each pixel with an intensity value. Figure 7 shows the image that has been processed to get the pixel value of the image perimeter.

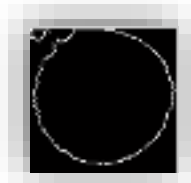

Figure 7. Image with Perimeter

The last process is calculating eccentricity. This process is used to identify differences in shape between normal blood and blood that has blood lipid abnormalities. Blood that has blood lipid abnormalities is flatter than normal blood. The three features, namely area, perimeter, and eccentricity, will be used as input for the artificial neural network.

\section{Blood Fat Abnormality Detection}

\section{ANN Training for Detection of Blood Fat Abnormalities}

The data used in the ANN training process for detecting blood lipid abnormalities were 40 single red blood cell image data, consisting of 22 normal blood cell images and 18 blood cell images with blood lipid abnormalities. The input data for this training process is the value features of the digital image processing that has been done previously. Table 1 shows the data from the Backpropagation network training for the detection of blood lipid abnormalities.

Table 1. Backpropagation network training results

\begin{tabular}{ccccc}
\hline Learning Rate & $\begin{array}{c}\text { Maximum } \\
\text { Epoh }\end{array}$ & Neuron & Number of Iteration & Accuracy (\%) \\
\hline 0.3 & 100 & 3 & 100 & 95 \\
0.3 & 1000 & 20 & 1000 & 97.5 \\
0.5 & 100 & 2 & 55 & 92.5 \\
0.2 & 1000 & 20 & 1000 & 55 \\
0.7 & 100 & 2 & 100 & 95 \\
0.7 & 1000 & 10 & 1000 & 70 \\
0.9 & 500 & 3 & 500 & 95 \\
\hline
\end{tabular}


Based on Table 1, it is shown that the changes in the values of the manipulation variables that cause differences in the level of accuracy are shown. The highest accuracy of $97.5 \%$ occurs at a learning rate setting of 0.3 , a maximum epoch of 1000, and 2 layers of neurons. Meanwhile, the fastest number of iterations is 55 iterations from a maximum of 100 iterations. However, the resulting accuracy is only $92.5 \%$.

\section{ANN Testing for Detection of Blood Fat Abnormalities}

Testing the Backpropagation network is the same as testing the training data, but the data used in the testing process of the Backpropagation network is different from the data for training. The data used for the testing process is 20 data, consisting of 10 normal images and ten images with blood lipid abnormalities.

The feature weights and bias weights used in the Backpropagation network testing process are the final feature weights and the final bias weights obtained from the training or learning process. The results of testing the Backpropagation network for blood fat detection can be seen in Table 2.

Tabel 2. Backpropagation network test results

\begin{tabular}{ccccc}
\hline $\begin{array}{c}\text { Learning } \\
\text { Rate }\end{array}$ & $\begin{array}{c}\text { Maximum } \\
\text { Epoh }\end{array}$ & Neuron & Number of Iteration & Accuracy (\%) \\
\hline 0.3 & 100 & 3 & 100 & 80 \\
0.3 & 1000 & 20 & 1000 & 85 \\
0.5 & 100 & 2 & 55 & 80 \\
0.2 & 1000 & 20 & 1000 & 85 \\
0.7 & 100 & 2 & 100 & 80 \\
0.7 & 1000 & 10 & 1000 & 80 \\
0.9 & 500 & 3 & 500 & \\
\hline
\end{tabular}

\section{Program Interface}

The initial view of the blood fat abnormality detection is shown in Figure 8. This program consists of three menus, namely Image Process, Backpropagation, Help, and Exit. The Backpropagation menu consists of Training, Testing, and Detection Programs.

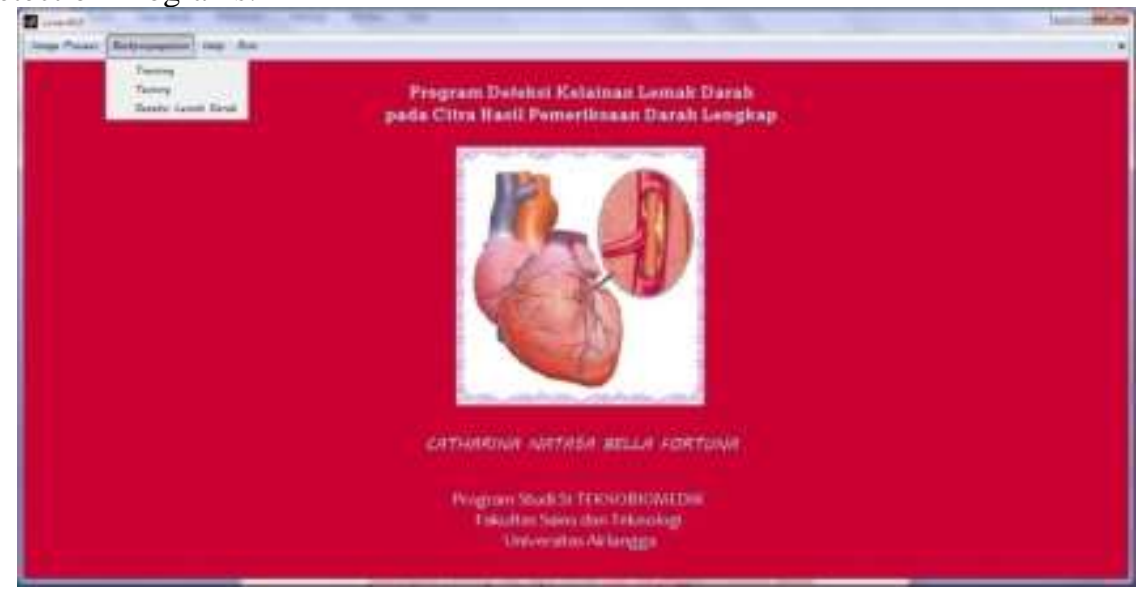

Figure 8. The main view of the program

The image processing program followed by the detection of blood lipid abnormalities is shown in Figure 9. The image processing process displayed is the original grayscale, thresholding, filling holes, and perimeter. Then proceed with the process of detecting blood lipid abnormalities. The detection results will be displayed in the detection results program. 


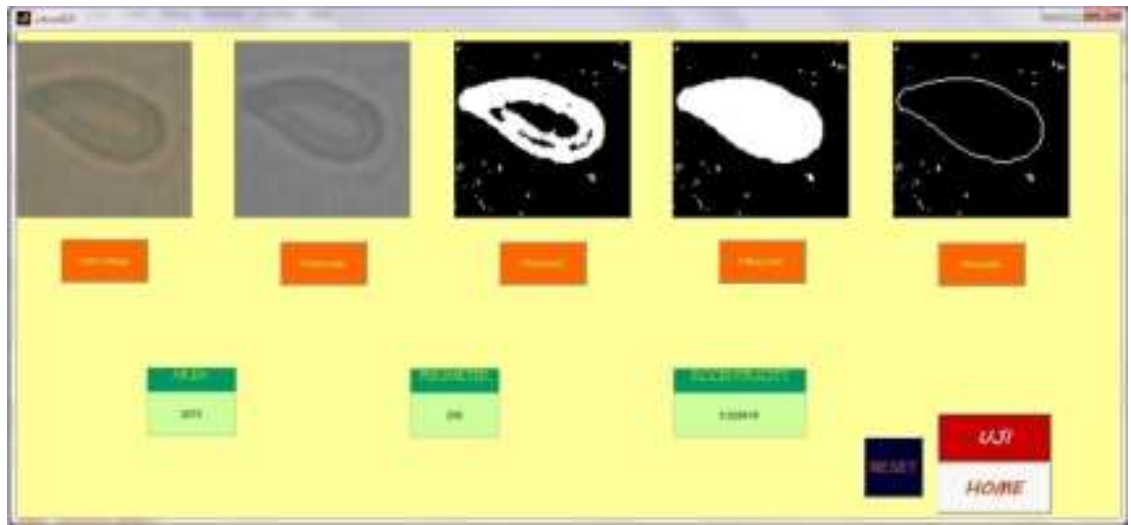

Figure 9. Image Process Program Display

The program displayed in Figure 10 is the program display of the detection results. The results of "Normal" or "Blood Fat Abnormalities Detected" will be listed according to the testing process results based on image processing.
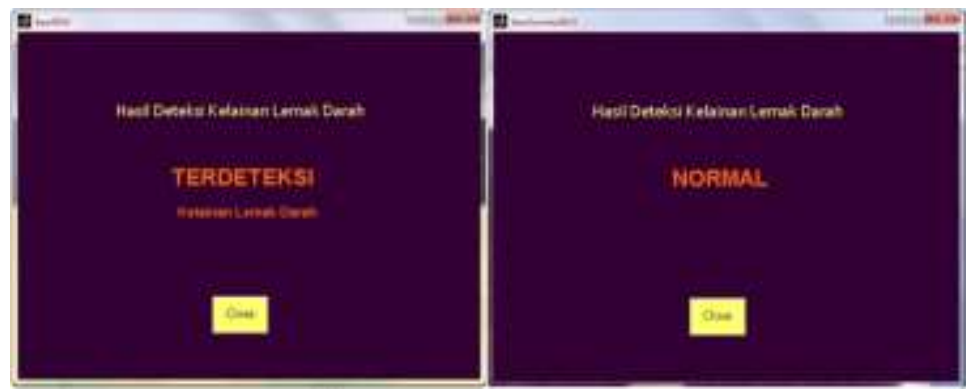

Figure 10. Detection Result Program Display

The training program display looks like in Figure 4.9, which displays red blood cells' area, perimeter, and eccentricity features. The Training Program also displays the final weight of the input, the final weight of the layer, the final weight of the input bias and the layer. The number of epochs is needed, and the user can change the value of the learning rate. Then the accuracy is displayed as a parameter of detection success by ANN.

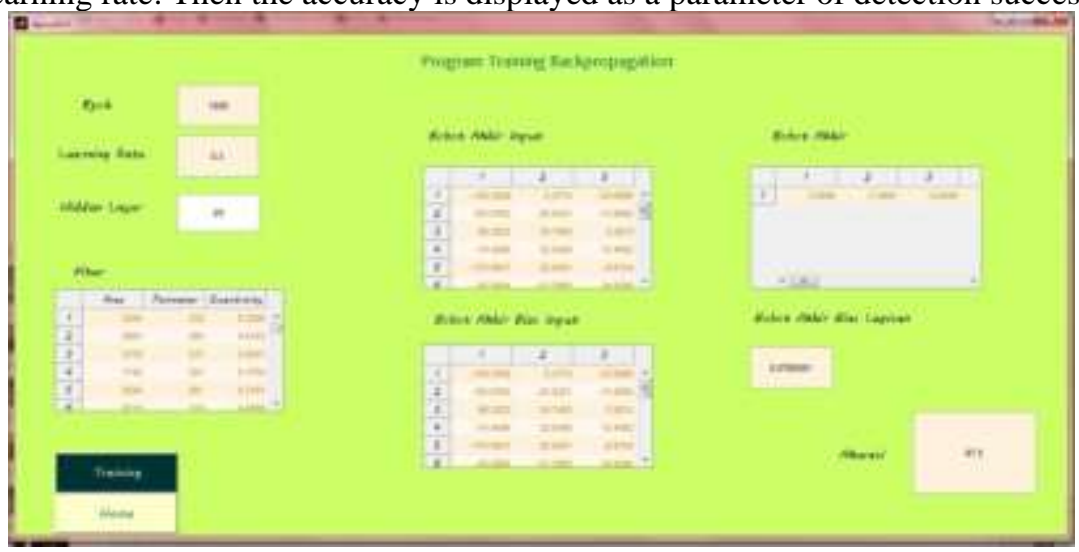

Figure 11. Display of Backpropagation Training program

The display of the Testing program looks like Figure 4.10, showing the area, perimeter, and eccentricity features of red blood cells. The results of the Backpropagation artificial neural network identification are matched with the targets of laboratory diagnosis results. The number of correct data is used to calculate the accuracy of the identification of the Backpropagation neural network. 


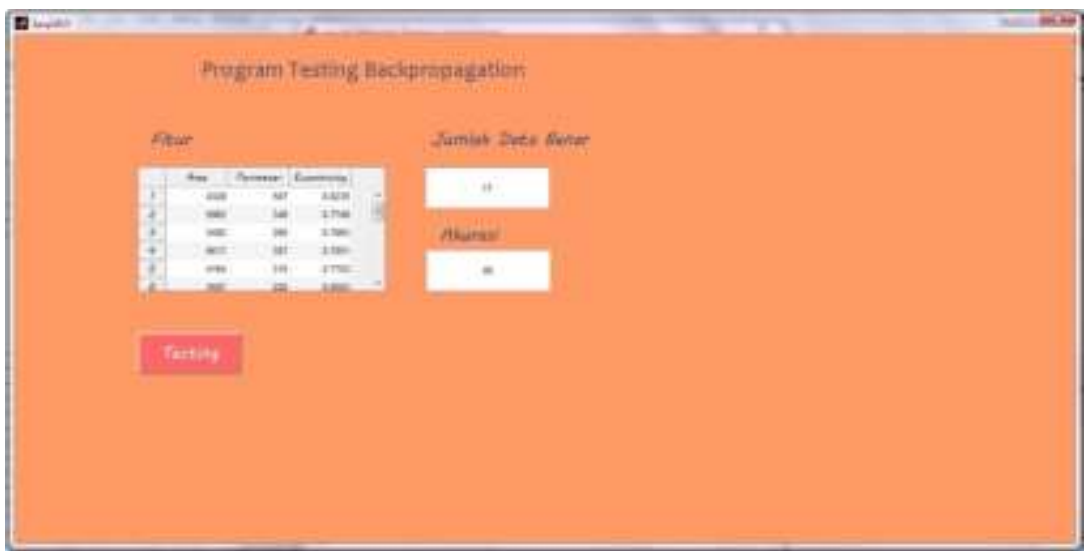

Figure 12. Display of Backpropagation Testing program

Instructions and assistance for using the blood fat abnormality detection are shown in the Help program and instructions in Figure 13.

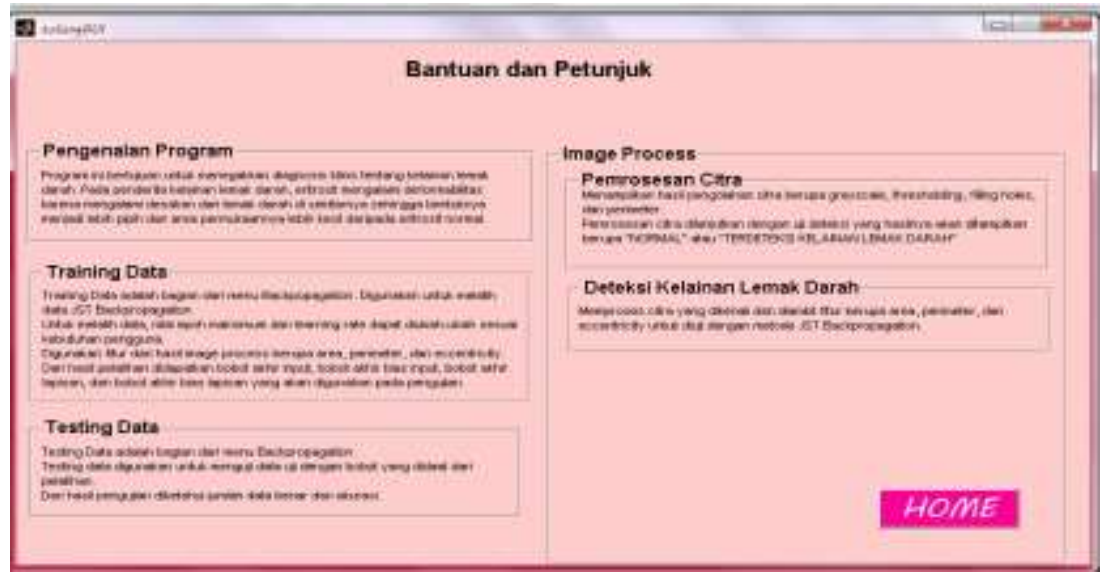

Figure 13. Help and Instructions program view

\section{CONCLUSION}

1. The area and perimeter of red blood cells are known by counting the number of pixels in the white image. The value of the image features used as the artificial neural network (ANN) input is as shown in the appendix. Another feature that can be used to detect blood lipid abnormalities is eccentricity. Red blood cells in blood lipid disorders undergo deformability so that their shape is flatter than normal red blood cells.

2. The process of detecting blood lipid abnormalities is carried out using Backpropagation ANN based on three input features, namely area, perimeter, and eccentricity.

3. The accuracy value for detecting blood lipid abnormalities reaches $85 \%$. Backpropagation ANN can be implemented to detect blood lipid abnormalities, but because the program accuracy is less than $95 \%$, it cannot be implemented in the medical field.

\section{REFERENCES}

1. Bain, Barbara J. 2006. Blood Cells: A Practical Guide. 4th Edition. Blackwell Publishing, Inc. Isbn-13: 9781-4051-4265-6.

2. Dougherty, Geoff. 2009. Digital Image Processing for Medical Applications. Published in the United States of America by Cambridge University Press, New York. ISBN-13 978-0-511-53343-3

3. Gonzales, Rafael C. and Wood, Richard E. 2002. Digital Image Processing. Second edition. Upper Saddle River, New Jersey 07458: Prentice-Hall,Inc. ISBN : 0-201-18075-8

4. Hartadi, Diaz dan Sumardi, R.Rizal Isnanto. 2004. Simulasi Perhitungan Sel Darah Merah. Transmisi, Vol.8 No.2 Hal.1-6. 
5. Hove,L.Van,. Schisano,T,.Brace,L. 2000. Anemia Diagnosis, Classification, and Monitoring Using Cell-Dyn Technology Reviewed for the New Millennium. Laboratory Hematology 6:93-108. Carden Jennings Publishing Co.

6. Kusumadewi, Sri. 2004. Membagun Jaringan Syaraf Tiruan Menggunakan Matlab\&Excel Link. Yogyakarta: Graha Ilmu. ISBN :979-3289-91-0

7. Koeswardani, R dan Boentoro, Budiman. 2001. Flow Cytometri dan Aplikasi Alat Hitung Sel Darah Otomatik Technicon H-1 dan H3. Malang: Laboratorium Patologi Klinik FK Unibraw RSUD Dr. Syaiful Anwar. 3 January 2007

8. McConnell, Thomas H. 2007. The Nature of Disease Pathology for the Health Professions. Philadelphia,PA. Lippincott Wiliams \& Wilkins. ISBN-13: 978-0-7817-5317-3.

9. Narayanan, Babu.2009. Influence of Cholesterol on Shape Parameters of Erythrocytes in Hyperglycemic Subjects. 77-81. School of Chemical And Bio-Technology, Sastra University, Thanjavur. India

10. Noriyuki,Tatsumi (April 2002). General Hematology. Erythrocyte Disorders (Chapter 2): 20 - 38 . Osaka City University, Graduate school of Medicine, Japan

11. Pamungkas, Adi. 2012. Perhitungan Otomatis Jumlah Sel Darah Merah dan Identifikasi Fase Plasmodium Falciparum Menggunakan Operasi Morfologi. Skripsi Jurusan Fisika, Fakultas Sains dan Matematika. Universitas Diponegoro Semarang. Juli 2012

12. Pattiserlihun, Alvama.dkk., Aplikasi Jaringan Saraf Tiruan (Artificial Neural Network) pada Pengenalan Pola Tulisan. Prosiding Pertemuan Ilmiah XXV HFI Jateng \& DIY. ISSN: 0853-0823

13. Praida, Arthania Retno. 2008. Pengenalan Penyakit Darah Menggunakan Teknik Pengolahan Citra dan Jaringan Syaraf Tiruan. Tugas Akhir Departemen Teknik Elektro Fakultas Teknik Universitas Indonesia.

14. Prasetyo, Eko. 2011. Pengolahan Citra Digital dan Aplikasinya Menggunakan Matlab. Yogyakarta: ANDI. ISBN : 978-979-29-2703-0

15. Putra, Darma. 2010. Pengolahan Citra Digital. Yogyakarta: ANDI. ISBN: 978-979-29-1443-6

16. Russ, John C. 2007. The Image Processing Handbook. $5^{\text {th }}$ edition. United States of America: Taylor \& Francis Group,LLC. ISBN 0-8493-7254-2

17. Sapp, J.Philip. Eversole, Lewis R. George P. Wysocki. 2008. Contemporary oral and maxillofacial pathology. Chapter 12: Diseases of Blood page 394-395. Mosby. University of Michigan. ISBN 0323017231, 9780323017237.

18. Siang, J. 2005. Jaringan Syaraf Tiruan \& Pemrogramannya Menggunakan Matlab. 2nd edition. Yogyakarta: Penerbit Andi.

19. Setsirichok, Damrongit.dkk.2011. Classification of Complete Blood Count and Haemoglobin Data by a C4.5 Decision Tree, a Naive Bayes Classifier and a Multilayer Backpropagation for Thalassaemia Screening. ScienceDirect. Biomedical Signal Processing and Control. Elsevier. doi:10.1016/j.bspc.2011.03.007

20. Sumathi, S. Paneerselvam, Surekha. 2010. Computational intelligence paradigms: theory \& applications using MATLAB. United States of America : Taylor \& Francis Group, LLC. ISBN 978-1-4398-0902-0

21. Tahir, Zulkifli,dkk. 2012. Analisa Metode Radial Basis Function Jaringan Saraf Tiruan untuk Penentuan Morfologi Sel Darah Merah (Eritrosit) Berbasis Pengolahan Citra. Laboratorium Kecerdasan Buatan. Jurusan Teknik Elektro, Universitas Hasanuddin. Forum Pendidikan Tinggi Teknik Elektro Indonesia (FORTEI) 2012

22. Tcheslavski, Gleb V. 2009. Morphological Image Processing: Basic Algorithms. Spring 2009. http://ee.lamar.edu/gleb/dip/index.htm

23. Warni, Elly. 2008. Penentuan morfologi sel darah merah (eritrosit) Berbasis pengolahan citra dan jaringan syaraf tiruan. Jurnal Ilmiah "Elektrikal Enjiniring” Universitas Hasanuddin. Volume 07/No.03/OktoberDesember/2009.

24. Wu,Qiang. Merchant, Fatima A. Castleman, Kenneth R. 2008. Microscope Image Processing. www.books.elsevier.com. ISBN: 978-0-12-372578-3 